\title{
Spontaneous broad ligament haematoma following a normal vaginal delivery
}

\author{
Dheeraj Yalla, Alaka N Nadar, Usha Rani G \\ Correspondence: Dr Alaka N Nadar, Senior Resident, OBGYN, SRMC, Chennai, Tamilnadu, \\ India; Email - alka.nadar1988@gmail.com
}

Distributed under Attribution-NonCommercial-ShareAlike 4.0 International (CC BY-NC-SA 4.0)

\begin{abstract}
Broad ligament haematoma is a rare complication of a normal vaginal delivery. We report one such case of a woman who developed this complication within $3 \mathrm{hrs}$ of normal vaginal delivery. Diagnosis was confirmed by clinical features and transabdominal ultrasound. Based on patients haemodynamic instability surgical management in the form of obstetric hysterectomy was done.
\end{abstract}

Keywords: Normal delivery, haematoma, broad ligament.

Broad ligament haematoma is a very rare event following a spontaneous vaginal delivery with an incidence of 1: $20,000{ }^{1}$. Usually these haematoma are the results of upper vaginal, cervical or uterine tears extending into uterine or vaginal arteries. Various predisposing factors like precipitate labour, caesarean delivery, operative vaginal delivery or trauma to the abdomen have been discussed in the literature ${ }^{2}$.

\section{Case report}

A 33 years old $\mathrm{G}_{2} \mathrm{P}_{1} \mathrm{~L}_{1}$, with previous normal vaginal delivery was admitted in labour room at 38 weeks of gestation in active labour. Artificial rupture of membrane (ARM) was done at $6 \mathrm{~cm}$ of cervical dilatation. Within 20 minutes patient delivered a healthy male baby of weight $3.710 \mathrm{Kg}$ without any complication. No evidence of cervical or vaginal tears were noted. Right medio lateral episiotomy was sutured in layers.

Three hours following delivery, patient complained of severe perineal and abdominal pain along with inability to void urine. On examination, patient looked pale, pulse rate $-92 / \mathrm{min}$, blood pressure $-100 / 60 \mathrm{~mm}$ of $\mathrm{Hg}$, uterus well contracted above the level of umbilicus. Genital examination revealed that episiotomy was intact, mild ooze from episiotomy skin site was noted; no obvious vaginal or vulval swelling was felt. On per rectal examination no obvious boggy mass was felt. Patient vital further deterioted, fall of $\mathrm{Hb}$ to $8.1 \mathrm{gm} \%$ from admission $\mathrm{Hb}$ of $12.2 \mathrm{gm} \%$ was noted. Urgent transabdominal ultrasonography was done which showed a hypoechoic mass of $10 \times 4.3 \times 4 \mathrm{~cm}$ on the right side with a well contracted uterus. Broad ligament haematoma was confirmed. Based on patient haemodynamic instablity a decision of exploratory laparotomy was made.

Patients' coagulation status was assessed by thromboelastography test and adequate blood products were arranged. Bladder was catheterised with foley's catheter and clear urine was drained. Intraoperatively a huge haematoma $10 \times 5 \times 4 \mathrm{~cm}$ was seen anterior to rectus

Received: $22^{\text {nd }}$ March 2018. Accepted: $11^{\text {th }}$ September 2018.

Yalla D, Nadar AN, Usha Rani G. Spontaneous broad ligament haematoma following a normal vaginal delivery. The New Indian Journal of OBGYN. 2019; 5(2): 140-1 
muscle. On entering the peritoneal cavity haematoma was found in right broad ligament extending into right paracolic gutter posteriorly and space of retzius anteriorly (Figure 1).

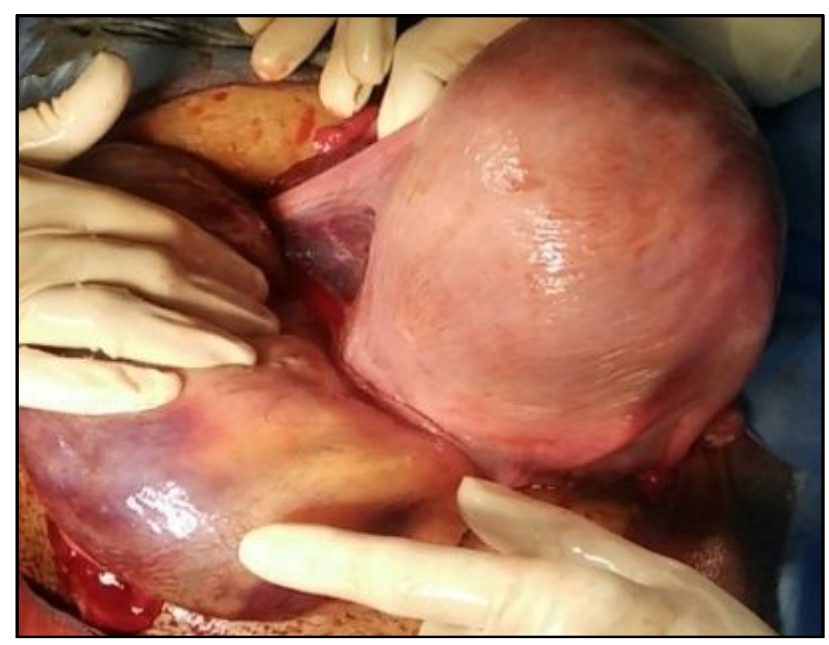

Figure 1: Broad ligament haematoma

Exact location of the bleeders could not be localized, hence a decision for subtotal hysterectomy was done. Three units of pack cell volume (PCV) were transfused. Two intraperitoneal drains were placed in situ. Haematoma was non expanding hence left undisturbed. Postoperatively patient was managed in high dependency unit. Catheter was removed after 2 days; patient resumed her normal bowel bladder habits. Stitched was removed on $10^{\text {th }}$ postoperative day and discharged. Four weeks later patient was followed up with an ultrasonography of abdomen which showed a resolving haematoma with size significantly reduced.

\section{Discussion}

Para genital haematoma are two types - supralevator and infralevator. Supralevator haematoma spreads upward and outward beneath the broad ligament. Our case is an example of supralevator haematoma. It can be silent and may not cause any obvious vaginal bleeding ${ }^{3}$. Clinical symptoms are vague with persistent perineal pain, urge to defecate, unable to void within first few hours of delivery.

Imaging modalities like transabdominal/ transvaginal ultrasound confirms the diagnosis. Broad ligament haematoma can be managed both conservatively and surgically depending on patient haemodynamic status, size and rate of haematoma expansion. Small non spreading ones can be managed conservatively however larger ones might need internal illiac artery ligation, or even hysterectomy ${ }^{4}, 5$. Our patient was haemodynamically unstable at the time of diagnosis and given the circumstances that the haematoma was expanding we decided for the surgical management i.e subtotal hysterectomy.

\section{Conclusion}

Broad ligament haematoma is a very rare event following a spontaneous vaginal delivery. A high degree of clinical suspicion is necessary for diagnosis of such rare complication. Resuscitation, volume replacement, and surgical exploration are the key steps in the management.

\section{Conflict of interest: None. Disclaimer: Nil.}

\section{References}

1.Saleem N, Ali HS, Irfan A, Afzal B. Broad ligament hematoma following a vaginal delivery in primigravida. Pak J Med Sci. 2009; 25: 683-5.

2.Holtz RS. Massive hematoma of the broad ligament complicating cesarean section; report of a case. J Int Coll Surg. 1959; 31(2): 188-91.

3.Edmonds K, editor. Dewhurst's Textbook of Obstetrics \& Gynecology. London: Blackwell Science; 2008.

4.Muthulakshmi B, Francis I, Magos A, Roy M, Watkinson A. Broad ligament haematoma after a normal delivery. $\mathrm{J}$ Obstet Gynaecol. 2003; 23: 669-70.

5.Maxwell C, Gawler D, Green J. An unusual case of acute postpartum broad ligament haematoma. Australia NZ J Obstetrics \& Gynecology. 1997; 37: 239-41.

\footnotetext{
Dheeraj Yalla ${ }^{1}$, Alaka N Nadar ${ }^{2}$, Usha Rani $\mathbf{G}^{3}$

${ }^{1}$ Post Graduate Student; ${ }^{2}$ Senior Resident; ${ }^{3}$ Professor, Department of Obstetrics and Gynaecology, SRMC, Chennai, Tamilnadu, India
} 